\title{
Paradoks: An Innovation in Javanese Dance Choreography
}

\author{
Silvester Pamardi \\ Indonesia Institute of the Arts, Surakarta, Indonesia
}

\begin{abstract}
Paradoks was a form of choreography that was based on Javanese choreography. This research was to develop Javanese choreography which tended to follow the pattern of court dance rules. The basic assumption of this research was Paradoks based on the Javanese choreographic form that had been through a process of development. This research was an innovation study in the Javanese choreography development. Javanese choreography had standard patterns as a form of noble dance. This meant that Javanese choreography had a high artistic level, not only from its historical factor but also because of its current position in the Palace. The problems examined in this study were: What was the form of Paradoks choreography? How was the innovation expression in the development of Javanese choreography in Paradoks dance? The specific objective to be achieved was to provide knowledge and understanding to the wider community about the pattern for forming the Paradoks choreography as an innovation in the development of Javanese choreography. The target of this research was to produce a written study on the innovation of developing the Paradoks choreography forming pattern in an internationally reputed journal. Another target was as a presentation of the research results to achieve the title of professor. This research used an artistic approach to the creation of art.
\end{abstract}

Keywords: Paradoks, motion pattern, choreography

DOI: $10.7176 / \mathrm{ADS} / 79-06$

Publication date: December $31^{\text {st }} 2019$

\section{Introduction}

Art that had become custom and tradition actually was when these custom forms were considered not to have a bad impact. As the development of society toward modern life, old habits began to change. The development of people's way of thinking had changed the belief system into a new knowledge system, including a way of seeing the need to package art. One thing that had been maintained in the general pattern of old habits was the association of art with the life of the palace tradition which was once the center of government, and had now become the center of culture and tradition. This change in way of thinking also influenced the view that court art, especially dance, had valuable patterns and high aesthetic value. One of the reasons for producing aesthetic performances of traditional arts was related to the formation of human character and mental development of a noble cultural personality.

Dance was an expression of human feelings expressed by the motions of human body. The motion in dance was not the movements that we did everyday (real movements of someone who carried out daily activities), but were movements that had undergone processes and changes from daily movements, ie movements that had been specifically processed based on feelings, intuitions, expressions, imagination, perceptions, and interpretations that led to the power of aesthetic experiences that were already presentative (Sutiyono, 2012: 40).

The palace dance was a reflection of Javanese expression centered on the palace. The palace dance had two functions, namely functions relating to traditional or religious ceremonies and functions related to entertainment. Dance for ceremonies was usually sacred and had magical powers, and dance related to entertainment was usually just a means of socializing and pleasure (Jazuli, 1989: 60).

The reflection of culture in Javanese art as a result of ideas-organizing which became a collective agreement was then presented in the form of artistic expression. Expression was an outward manifestation of an inner attitude that revealed a person's thoughts, or a variation of psychological statements in the form of feelings, moods, behavior, and emotions (Ross, Stephanie, 1996: 689). The phenomenon that appeared in this study was that the artistic expression presented to the Javanese people had a fairly close connection with beliefs, ideas, understandings and beliefs. Javanese dance which did not escape the principles of Javanese cultural expression, formed a Javanese choreographic concept.

Paradoks was a dance model developed from Javanese choreography. There were three character figures depicted in Paradoks dance. First, the old figure who was sick but could not die because he made a pact with the gods. He had an obsession to eradicate crime on earth. God gave the ability to never die, unless he was killed by someone incarnated by Vishnu. He got old. Disease spreaded to his body and he was tortured. Finally he was bored living life.

The second part, (transformation) was the depiction of a knight who eradicated evil. This was a figure that became his dream and obsession (Topeng Panji). The third part, (transformation) was a depiction of excessive ambition, leading to greedy, arrogant, uncontrolled nature (Topeng Klana). The fact showed that Paradoks was a novelty when viewed from the choreography and accompanying music. Even so, Paradoks still used the rules of 
Javanese dance choreography. Innovation could be seen in the selection of dancers, the selection of movement patterns, and accompanying music. The chosen form of choreography Paradoks looked different from classical Javanese dance. Paradoks accentuated more expression of the character of the mask. The motion pattern was the result of Surakarta style Javanese classical dance patterns development. This could be seen in the foot movements, facial expression of the mask, and hand movements.

The Paradoks performance was an innovation and development phenomenon in Javanese choreography in the form of a single dance. Paradoks dance was the creation of a Javanese choreography model that was different from other Javanese dances, especially court dances. This phenomenon became an embodiment of Javanese choreography development model outside the palace walls. But what raised doubts was whether the Paradoks was included in the realm of Javanese dance, even though it had experienced development in choreography, or not.

Paradoks was considered as a choreography that was the result of innovation. This was because Paradoks was a dance with Javanese choreography composition, but in its performance had experienced the innovation of motion, dance music, makeup, and costumes. Based on these thoughts, research was needed to uncover the following matters. a. What was the innovation form in Javanese choreography while Paradoks was developed? b. How was the process of creating Paradoks dance?

The purpose of this study was to provide knowledge and understanding to the wider community about Paradoks dance as a form of Javanese choreographic innovation. The specific purpose of this research was to provide knowledge and understanding to the public regarding the forms of innovation in Javanese choreography.

Javanese dance as a traditional art attracted many people to learn, either as a journalistic report or in the form of scientific studies. From the data found, we could find out the following writings about Javanese dance.

Karonsih (Maryono, 1990/1991) discussed the process of creating the Karonsih dance created by Maridi. The book contained dance ideas, how to pour ideas into dance forms, song selection, accompaniment selection, motion vocabulary, as well as makeup and costumes worn. Karonsih dance was usually performed at wedding ceremonies. This dance had a significant influence on the emergence of couple dances with romance theme.

Tari Prawira Watang Karya Maridi (Sriyadi, 1992) discussed the process of creating Prawira Watang dance. This book also discussed dance ideas, how to pour ideas into dance forms, song selection, accompaniment selection, motion vocabulary, as well as the makeup and costumes worn.

Kajian tentang Pencak Silat dalam Beberapa Ragam Gerak Tari Tradisi di Surakarta (Mathius Supriyanto, et al., 1995), was a book that discussed pencak silat which was included in traditional dance. This book explored and revealed the background of the various movements of pencak silat and their connection to traditional dance, especially the development of pencak silat in dance performed by Maridi.

Pengaruh Rantaya Gagah terhadap Kualitas Penari Gagahan di Lingkungan Gaya Surakarta (Suharji, 1991), this book described the benefits of rantaya dance for the quality of gagahan style dance. It was explained in this book, that Maridi argued about the need to learn rantaya, demands in rantaya learning, the use of gending as accompaniment music, rantaya technical training, method of rantaya training, short-term effects of rantaya, longterm influence of rantaya, and procedure of rantaya learning.

Various writings about Javanese dance above showed that Javanese choreography innovation had taken place and was a source of reference to avoid duplication in the creation and analysis of Paradoks dance. Therefore this research on Maridi biography could be said to be original research. This kind of research was the first time conducted.

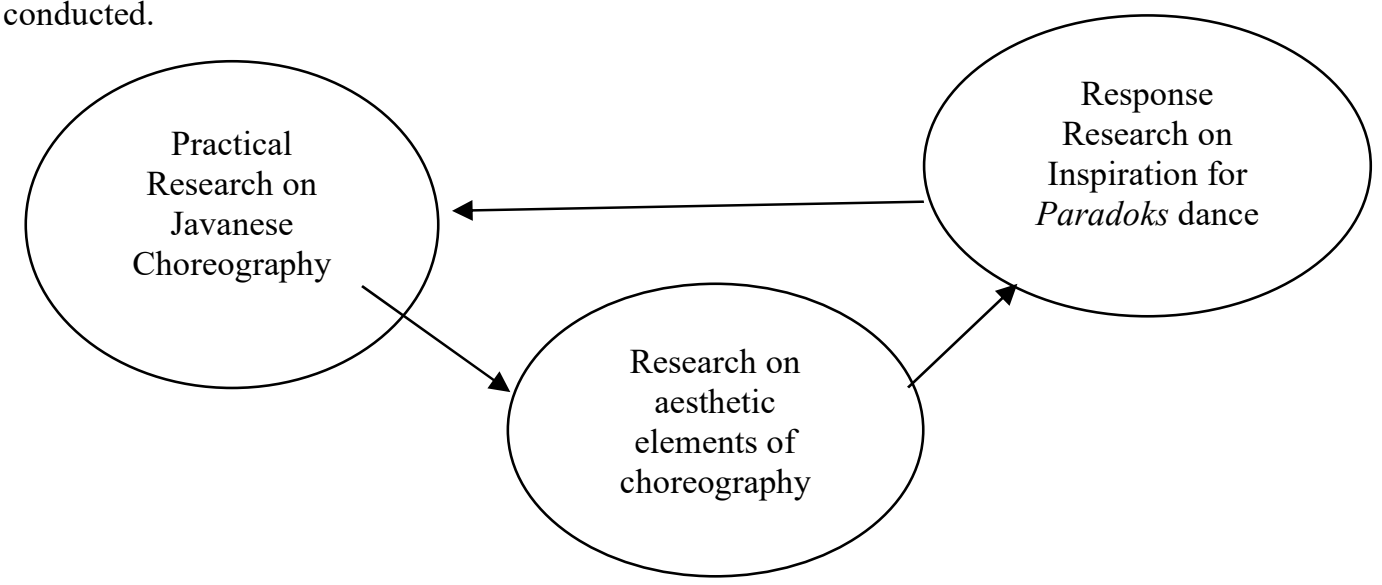

Academic art creation was carried out through several stages which could be scientifically justified. Art creation or artistic research was a scientific activity: research by practice. That was, research on phenomena that was occured in the community which then triggered ideas expressed in art practices that produced works of art. Therefore a researcher needed to carry out steps systematically in the process of creating art.The steps in the process of creating art were as followed. 
Participant and non-participant observation. Participant observation was carried out by being directly involved in Javanese dance as a dancer. Technical observations in this activity produced the ability to perform Javanese dance motions and to directly experience by dancing to the music. This was done to compile the motion techniques and to compose dance music to Paradoks. Non-participant observation was carried out by observing Javanese dance performances in Surakarta. It was hoped that this activity would provide a full understanding of the show presentation form. Interviews were conducted with informants to get information about Javanese choreography. Interviews with Javanese dance artists were intended to get information about Javanese dance motion techniques, dance music, and equipments. In addition, interviews were conducted with the public and the audience to get responses on various Javanese dance performances. Literature study was conducted to find references relating to Javanese choreography and customs to complement knowledge about the function of Javanese dance.

\section{Discussion}

This research not only produced written concepts but also produced Javanese choreographic innovation models. At this stage there was a flow in the process of creating Paradoks. Academically, a work of art was created not only by intuition, but by conducting research through systematic stages. Dance as a performance art served a purpose and was in the context of spectacular entertainment, recreation or therapy, or the projection of an artistic skill (Slamet: 2016, 13). This statement was the premise that dance creation also required research to produce a form of performance.

Dance or joged had a raw material which in Javanese terms was called 'solah' (Slamet: 2014, 36). Javanese dance had standard rules, so the preparation must fulfill these rules. In dance, the human body was the main ingredient and gestures were the basic ingredients of expression tools. This understanding in Java was known as 'ebrah' (Slamet: 2016, 16). The steps for creating the Paradoks dance were as followed.

a. Observation. It was a method that was carried out at an early stage of research. The implementation of this method was by observing the activities of the Javanese community and the existence of Javanese dance with standard rules. This observation was also carried out on the Javanese community at Wesleyan University. From the results of this observation, we obtained data about Javanese dance forms that could be developed as a choreographic innovation, related to the situation and conditions in Unites States of America. In addition to gamelan which was an accompaniment music instrument, human resources that could play gamelan were difficult to find. So I made an adaptation in the form of a choreography innovation that was based on Javanese dance.

b. Exploration was the act of looking for possibilities based on observational data into a single dance performance titled Paradoks. First, I sought the motion of an elderly, sick man. So, motion was described by carrying a stick. Then I explored movements to mimic the way an old man walked. This exploration was carried out in the open by the river. The movements obtained were then used as material for the creation of an old figure that was ill but could not die, because he had an agreement with a god so he could not die, except at the hand of a Vishnu's incarnation. Further exploration was in the form of transformation as a knight who eradicated crime, with all his obsessions which were illustrated by the Topeng Panji dance. This description was because in Java, Panji was known as a knight. At the end (third part), was a transformation in the form of arrogant ambition, wrath, uncontrolled greed. The expression used was the Topeng Klana dance. Klana in the Panji story was someone who was greedy and arrogant for his powers. Observations of the figures and motions were used as data in the experiment.

c. Experimentation was a method of exploration continuation. An experiment was an attempt to search for model possibilities. From the experiments, an appropriate technique, pattern, and model would be obtained to be used as material for reflection. The initial stage was to experiment with the motion of a topeng tua style dance, while sticking to the basic motion of Javanese dance. In addition to the patterns of the feet, hands, and body, the expression of the mask still used the Javanese topeng dance motion pattern. At this stage the dance music was tried by mixing Javanese gamelan and Chinese music. Then an experiment was carried out on the transformation, namely the Topeng Panji motion with Jawa alus dance patterns. In the final section, experiments were carried out on the motions of the Topeng Klana. However, the motions obtained from the results of exploration were motions of Javanese dance innovation, especially the gagahan dance moves of the Klana character.

d. Contemplation was a re-examination form of exploration and experimentation, before determining the model form of Paradoks dance performance. When contemplating, I considered several prototypes produced. Contemplation needed to consider the condition of the community, performance models, and users. In other words, I as the creator needed to consider the way the model was created, used, and published.

e. Formation. This stage was carried out before the dance was socialized or taught. At this stage, costumes, makeup, and dance music were chosen and arranged. Formation was done after the experimental stage and contemplation was considered to have achieved the desired goal. This stage was also the phase to analyze and ensure that dance patterns were in accordance with the theme and story pattern.

f. Training. This was an important stage. The training stage was also a phase of socialization for the dance model 
that was about to be staged. This training served to strengthen the dance created, in terms of motion, costume and makeup, dance music, and stage settings. Preparation for the performance was marked by a form of practice in an effort to harmonize every aspect of the choreography created.

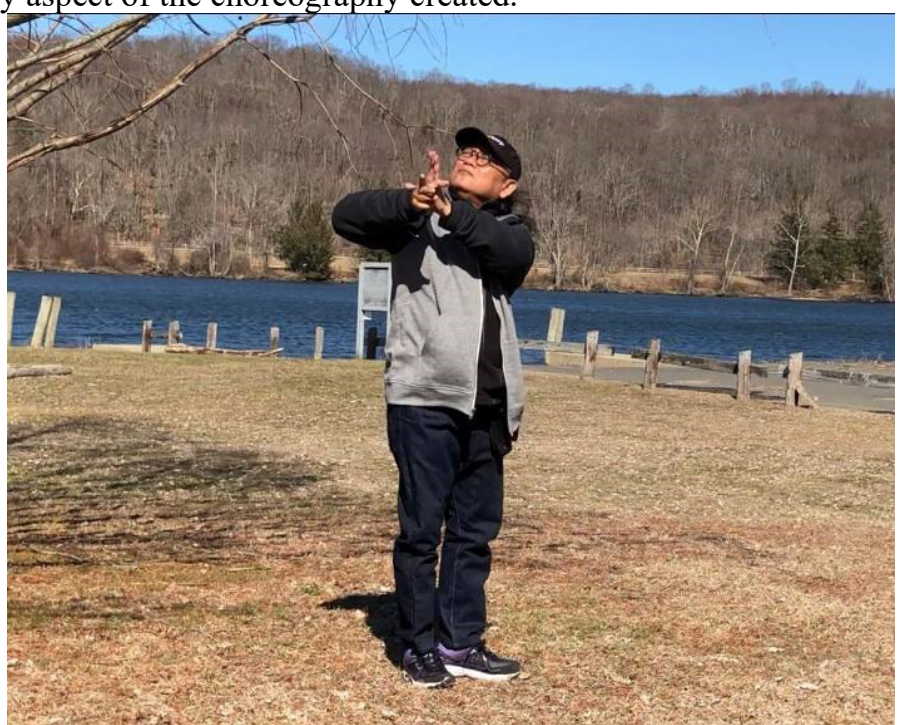

Pic. 1. Exploration in the Open to Look for Possible Motion (Photo: S. Pamardi, 2018)

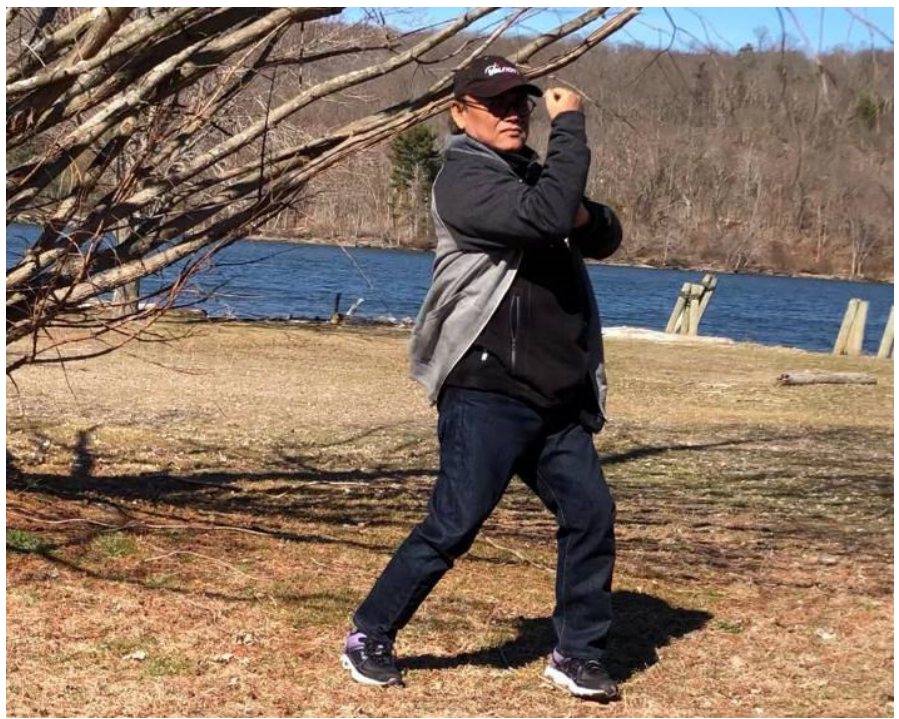

Pic.2 Experimented with the Mighty Motions of Topeng Klana (Photo:S. Pamardi, 2018)

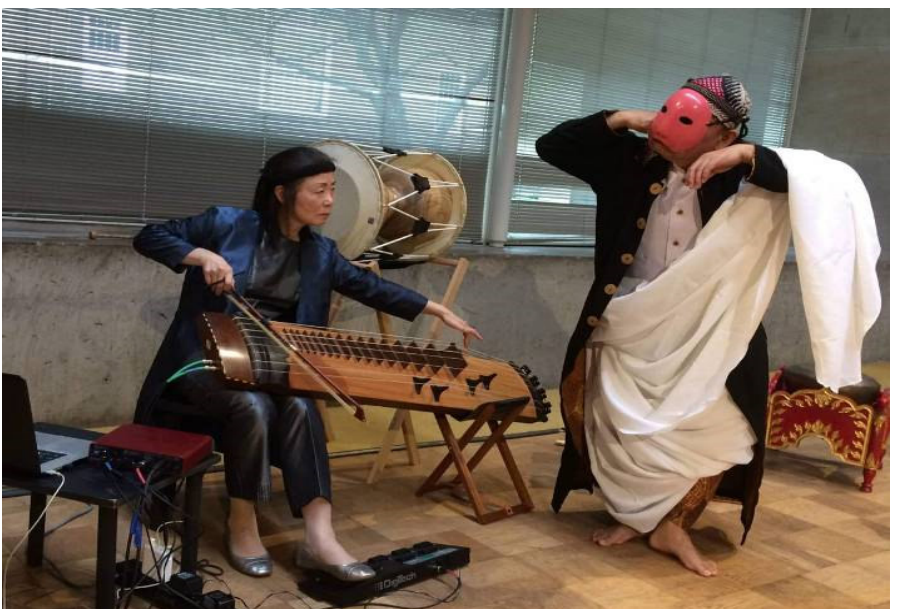

Pic.3. Topeng Tua Figure and a Musician (Photo: S. Pamardi, 2018) 


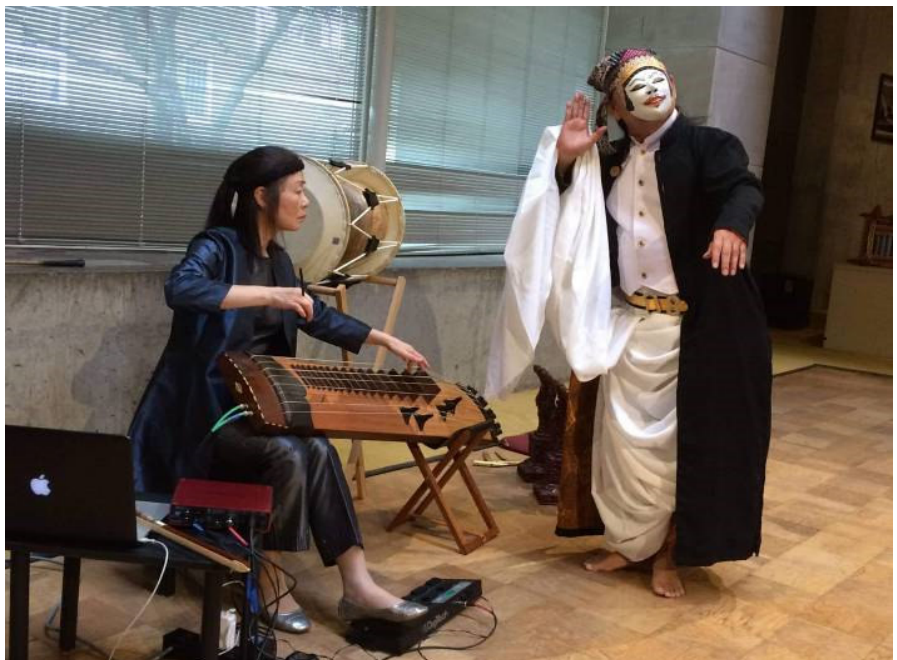

Gb.4. Topeng Muda (Topeng Panji) Depiction of a Knight's Ambition (Photo: S. Pamardi, 2018)

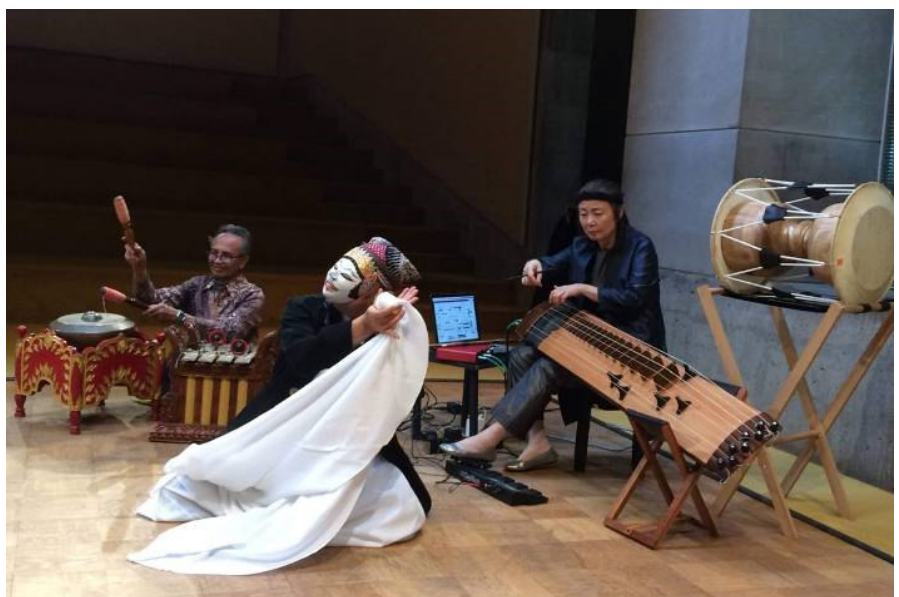

Gb. 5 Jengkeng Pose on the Development of Jawa Alus Dance (Photo: S. Pamardi, 2018)

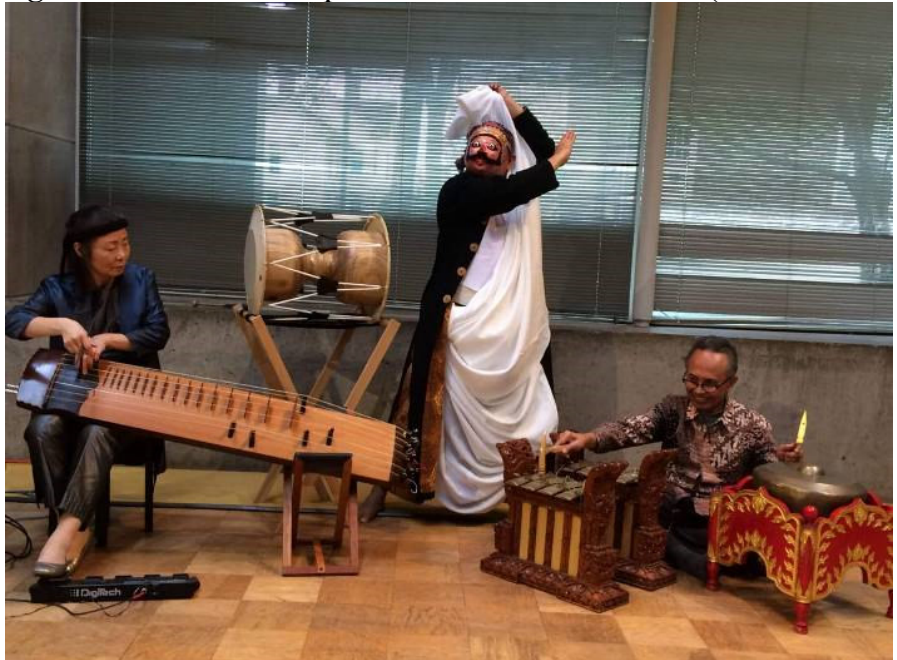

Gb. 6. Klana Figure, a depiction of greediness, Still Using Javanese Dance Gesture (Photo: S. Pamardi, 201

\section{Conclusion}

Paradoks was an innovation of Javanese choreographic dance made based on research. This dance was created overseas and performed overseas, which was at Wesleyan University, United States. This dance was made through several stages of research that gave rise to ideas, then poured into the Paradoks dance. The creation of Paradoks was through academic research. This work did not appear suddenly, but through systematic research steps. 
The treatment of academic research in an art creation went through several stages. In addition to the usual stages of research in general, such as observation, interviews, and literature studies, and reseach by practice, the stages of the creation process were added, namely environmental observation, ideas created, exploration, experimentation, reflection, formation, and training. The results of this study indicated that dance also required research and creation by carrying out systematic scientific steps.

\section{References}

Edy Sedyawati, Pertumbuhan Seni Pertunjukan Sinar Harapan, Jakarta, 1981.

Edy Sedyawati, Penataan Tubuh dalam Kebudayaan Jawa, Pustaka Jaya, Jakarta, 1987.

Errington, Shelly, "Tempat Benda-benda Pusaka di Lawu", dalam pusat Simbol dan Hiraraki Kekuasaan Penyunting Lorraine Gesick, Yayasan Obor, Jakarta, tt.

Geertz, Clifford., Abangan Santri, Priyayi dalam Masyarakat Jawa, Pustaka Jaya, Jakarta, 1983.

Haries Soetarto, "Tari Nuduhake Karakter", Mekarsari tanggal 17 Oktober 1990.

Yudanegara, G.B.P.H., Kawruh Joged Mataram, Yayasan Siswa Among Beksa, Yogyakarta, 1982.

Kumadilaga, Serat Sastra Miruda, Alih bahasa Kamajaya dan Hadisucipta. Proyek penerbitan buku bacaan dan sastra Indonesia dan Daerah, Jakarta, 1981

Maria Darmaningsih, "Gambyong Pareanom: Studi kasus Nilai-nilai kewanitaan dalam Pura Mangkunegaran", Skripsi Sarjana Antropologi Tari, Institut Kesenian Jakarta, 1987.

Peursen, Van., Strategi Kebudayaan, Kanisius, Yogyakarta, 1976.

Pradjapangrawit, Wedhapradangga, Serat Sejarah Utawi Riwayating Gamelan (serat saking gotek) Alih aksara Sogi Sukidjo dan R. Ng. Renggasuhono, STSI Surakarta, 1980.

Rohmat Joko Prakosa, Tari Srimpi Dhempel, STSI Surakarta, 1990.

Slamet MD, ed, Garan Joged, Surakarta: Citra Sains LPKBN, 2014. , Melihat Tari, Surakarta: Citra Sains LPKBN, 2016.

Soedarsono, Wayang Wong: The State Ritual Dance Drama in Court of Yogyakarta, University Gadjah Mada Press, Yogyakarta, 1984.

Sartono Kartodirdjo, Pengantar Sejarah Indinesia baru; 1500-1900 dari Emporium sampai Imperium, Jilid I, Gramedia, Jakarta 1993.

Sastrakartika, Serat Kridhawayangga Pakem Beksa, Tri Murti, Solo, 1925.

Sri Sumarni, Tinjauan Struktur Tari Srimpi Sukarsih, STSI Surakarta, 1994 